Review

\title{
Enzyme-Catalyzed Modifications of Polysaccharides and Poly(ethylene glycol)
}

\section{H. N. Cheng ${ }^{1, *}$ and Qu-Ming Gu ${ }^{2}$}

1 Southern Regional Research Center, USDA Agricultural Research Service, 1100 Robert E. Lee Blvd., New Orleans, LA 70124, USA

2 Ashland Research Center, 500 Hercules Road, Wilmington, DE 19808, USA; E-Mail: qgu@ashland.com

* Author to whom correspondence should be addressed; E-Mail: hn.cheng@ars.usda.gov; Tel.: +1-504-286-4450; Fax: +1-504-286-4367.

Received: 24 April 2012; in revised form: 12 June 2012 / Accepted: 14 June 2012 /

Published: 21 June 2012

\begin{abstract}
Polysaccharides are used extensively in various industrial applications, such as food, adhesives, coatings, construction, paper, pharmaceuticals, and personal care. Many polysaccharide structures need to be modified in order to improve their end-use properties; this is mostly done through chemical reactions. In the past 20 years many enzyme-catalyzed modifications have been developed to supplement chemical derivatization methods. Typical reactions include enzymatic oxidation, ester formation, amidation, glycosylation, and molecular weight reduction. These reactions are reviewed in this paper, with emphasis placed on the work done by the authors. The polymers covered in this review include cellulosic derivatives, starch, guar, pectin, and poly(ethylene glycol).
\end{abstract}

Keywords: biocatalysis; carbohydrates; cellulosic derivatives; enzyme; guar; modification; pectin; poly(ethylene glycol); polysaccharides; starch

\section{Introduction}

Polysaccharides are found in most agricultural products and residues. In addition to being major food items, polysaccharides have been used extensively for their functional properties, such as thickeners, gelling agents, stabilizers, interfacial agents, flocculants and encapsulants, in such applications as food, adhesives, coatings, construction, paper, pharmaceuticals, and personal care [1-3]. For many 
of these applications, polysaccharides need structural modifications in order to improve or customize their properties. Over the years many chemical reactions have been used to modify existing polysaccharides [4-7].

In recent years biocatalysis has emerged as an active area of research and development [8-13]. One successful application of biocatalysis has been the use of enzymes to modify the structures of polysaccharides. As polysaccharides are natural materials, many enzymes are available in nature that can carry out these reactions. In addition, enzymes are often chemospecific, regiospecific and/or enantiospecific, enabling the synthesis of products with well-defined or stereospecific structures [14-17]. Another advantage is the mild conditions under which many enzymatic reactions can be done, often leading to products with less color or odor, and reduced levels of undesirable by-products. It may be noted that most of the polysaccharide modifications need not be carried out to high DS (degree of substitution, i.e., moles of additive per mole of polysaccharide residue) to give the desired end-use properties; thus many enzymatic reactions with relatively low yields can still be useful.

In this paper, several enzyme-catalyzed reactions of polysaccharides are reviewed, including ester formation, amidation, oxidation, glycosylation, and hydrolysis (Table 1). With these reactions, it is possible to carry out addition of specific functional groups onto polysaccharides, such as polar, charged, hydrophobic, or customized substituents, to reduce polymer molecular weight, or to cleave off unwanted substructures. In order to limit the scope of this paper, only reactions involving cellulose derivatives, guar, starch, and pectin are covered, with particular emphasis on the work done by the authors. Poly(ethylene glycol) is also included because it is amenable to most of the same reactions.

Table 1. Typical water-soluble polymers and modification reactions.

\begin{tabular}{lllll}
\hline Polymers & Structural Modification & Enzymatic Reaction & Property & Application \\
\hline cellulosics & hydrolysis & oxidation & solubility & thickener \\
guar & - MW reduction & ester formation & rheology & gelling agent \\
starch & - side group cleavage & amidation & interfacial effects & emulsifier \\
pectin & addition & glycosylation & gel formation & flocculant \\
polyethers & polar substituent & hydrolysis & water retention & encapsulant \\
& - charged functionality & & tensile & stabilizer \\
& - hydrophobe & & texture & binder \\
& - customized functionality & & etc. & etc. \\
\hline
\end{tabular}

\section{Cellulosic Derivatives}

Cellulosic derivatives (e.g., cellulose esters and ethers) have useful properties and are important commercial products [1-7]. Thus far, most applications of enzymatic reactions have concentrated on cellulose ethers, particularly hydroxyethylcellulose (HEC) and carboxymethylcellulose (CMC) $[14,15]$. Note that the structures shown in the figures for HEC are schematic; the $\left(\mathrm{CH}_{2} \mathrm{CH}_{2} \mathrm{O}\right)$ units are actually substituted statistically at positions 2, 3, 6 on the anhydroglucose and at - $\mathrm{OH}$ chain end. The structure for $\mathrm{CMC}$ is also schematic; the $\left(\mathrm{CH}_{2} \mathrm{COOR}\right)$ units are substituted statistically on the anhydroglucose. Likewise, the positions of the additives are shown schematically; they are actually substituted statistically, and the subscript $\mathrm{n}$ represents the degree of polymerization in all the figures. 


\subsection{Addition of Polar Substituents}

The nature of a substituent on cellulose has a large effect on the properties of the cellulosic derivative $[1,2]$. Thus, HEC is soluble in water at all temperatures, but methylcellulose starts to gel at about $45{ }^{\circ} \mathrm{C}$, and hydroxypropylcellulose precipitates from water at $40-45{ }^{\circ} \mathrm{C}$. An example of the effect of polar groups on solubility has been shown for acetylation of HEC [15] (Figure 1). The reaction was carried out by suspending HEC in N,N-dimethylacetamide (DMAc) and adding Lipase $\mathrm{P}$ (from Pseudomonas cepacia, Amano Enzyme USA, Elgin, Illinois). After thorough mixing, a slurry was obtained, which could be isolated to give the product. HEC is water-soluble, but when acetylated, the resulting polymer becomes much less soluble in water.

Figure 1. Lipase-catalyzed synthesis of acetylated hydroxyethylcellulose (HEC).

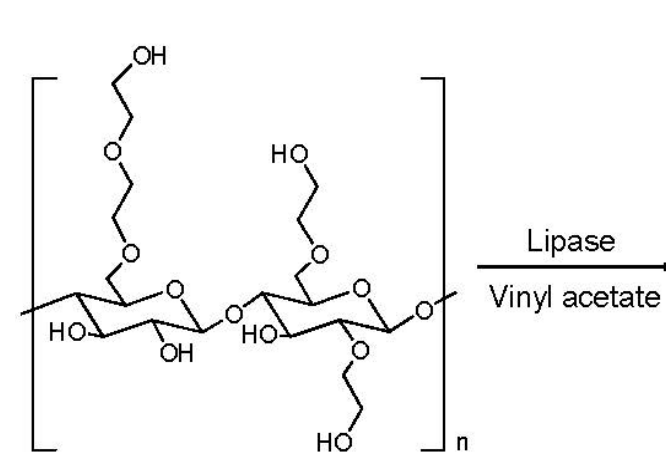

HEC

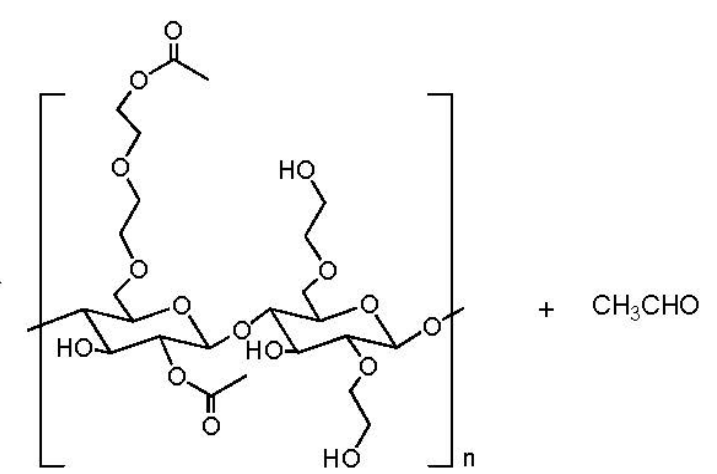

Acetyl-HEC

Another example is the graft polymerization of $\varepsilon$-caprolactone onto HEC through the catalysis of lipase (Figure 2) [18]. In this case HEC film was incubated with $\varepsilon$-caprolactone and porcine pancreatic lipase at $60{ }^{\circ} \mathrm{C}$ for $3-5$ days. The film was extracted with chloroform to remove any homopolymer that might have formed. The product was found to be HEC grafted with poly( $\varepsilon$-caprolactone).

Figure 2. Lipase-catalyzed graft copolymerization of $\varepsilon$-caprolactone.

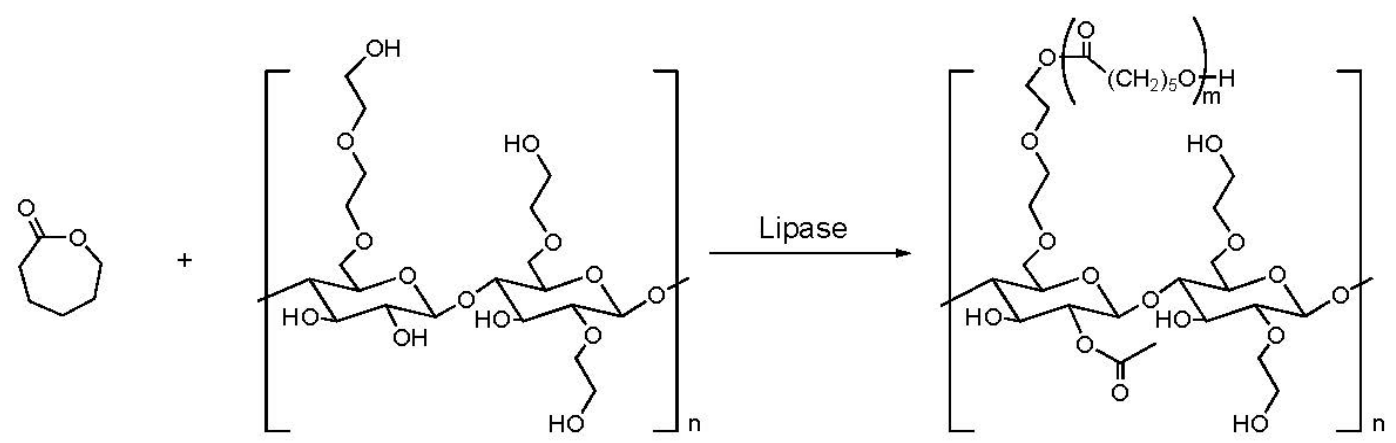

\subsection{Addition of Charged Substituents}

For some applications, the introduction of an electrically charged group to a polysaccharide can be highly desirable. Enzymes can be used to catalyze the addition of charged substituents onto cellulosic derivatives. For example, succinic anhydride was grafted onto HEC in the presence of a lipase (Figure 3) [15]. For this reaction HEC was suspended in DMAc, and succinic anhydride and Lipase P 
were added and then heated at $60{ }^{\circ} \mathrm{C}$ for $16 \mathrm{~h}$. A slurry was obtained from which the product was precipitated with acetone. Whereas this reaction can also proceed without the use of enzymes, the enzymatic process has the advantage of lower reaction temperature and higher degree of substitution.

Figure 3. Synthesis of succinated HEC.

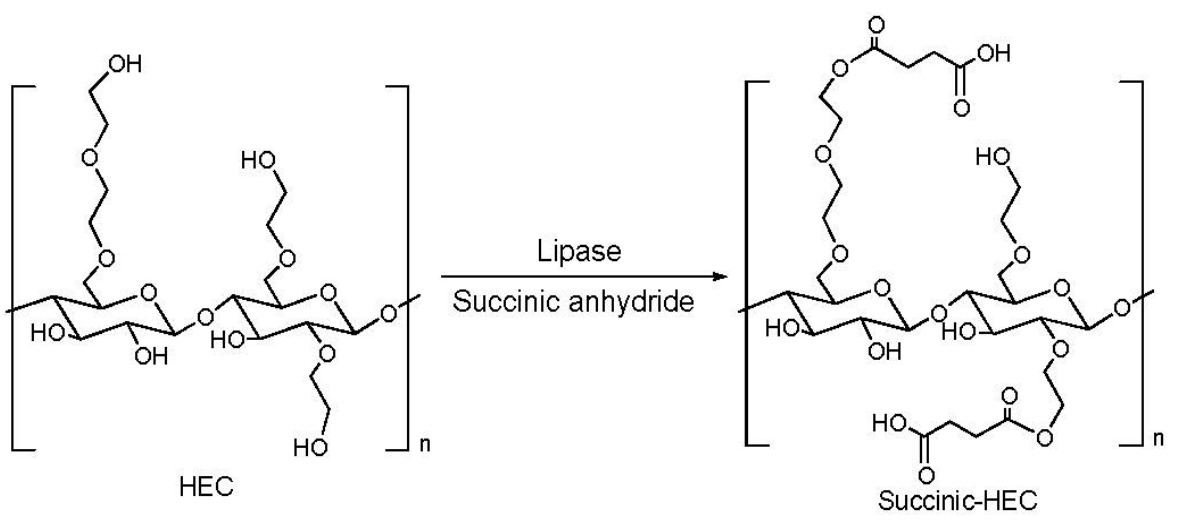

An alternative method of placing an anionic charge on HEC is to oxidize the HEC. An example was reported by $\mathrm{Hu}$, et al. [19], using in-situ generation of hypobromite catalyzed by lipase and coupled with oxidation with 2,2,6,6-tetramethyl-1-piperidinyloxy (TEMPO). In this way, the chain-end alcohols of both HEC and poly(ethylene glycol) were converted to carboxylic acids.

An example of the addition of a cationic charge to a polysaccharide is shown for the following reactions (Figure 4) with CMC and a diamine, where $\mathrm{X}=\left(\mathrm{CH}_{2}\right)_{\mathrm{m}}$, and $\mathrm{m}>2$. The reaction with CMC (where $\mathrm{R}=\mathrm{H}$ ) was found to proceed at 5\%-20\% efficiency for subtilisin Carlsberg, papain, and protease from Aspergillus saitoi in N,N-dimethylformamide (DMF) solvent. The reaction with CMC ester ( $\mathrm{R}=$ methyl or ethyl) was, however, more facile, and a higher efficiency was achieved [20].

Figure 4. Hydrolase-catalyzed amidation of carboxymethylcellulose (CMC) and CMC ester.

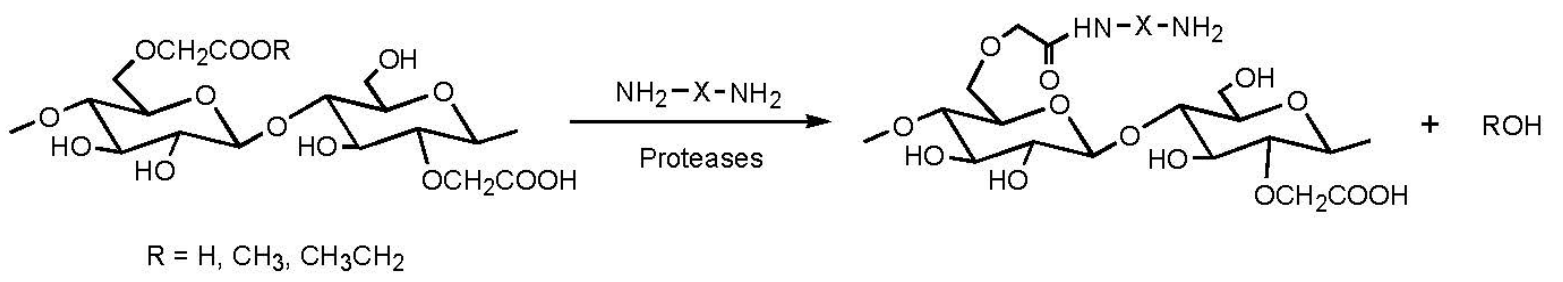

\subsection{Addition of Hydrophobic Substituents}

Hydrophobic modification is a common method to synthesize surfactants or rheology modifiers. The hydrophobes associate with one another in aqueous solutions at low concentrations, and thereby increase the viscosity of the solution at low shear frequencies [21]. Examples of commercial associative thickeners include hydrophobically modified HEC (HMHEC) [22], ethoxylated urethane (HEUR) [23,24], and alkali-soluble emulsion (HASE) [25-27]. Enzyme catalysis can be used to put a hydrophobic unit onto a cellulose derivative. For example, stearic ester was grafted onto HEC through the use of vinyl stearate (Figure 5) [28]. Since vinyl stearate is expensive, a more cost-effective route was reported using methyl stearate instead [15]. The latter reaction entailed a slower rate of reaction, but the rate could be accelerated by pulling a vacuum on the reaction. 
Figure 5. Hydrophobic modification of HEC.

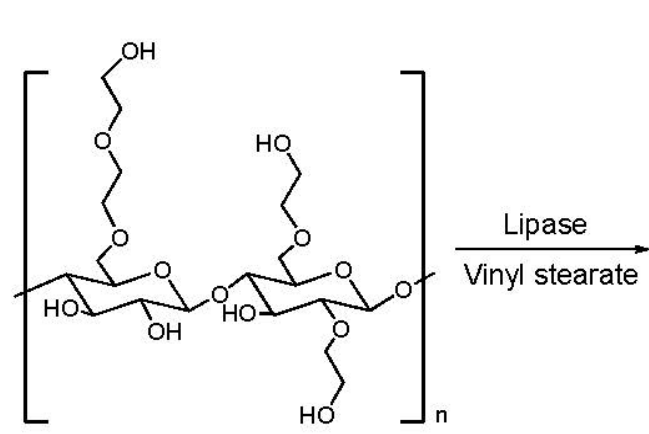

HEC

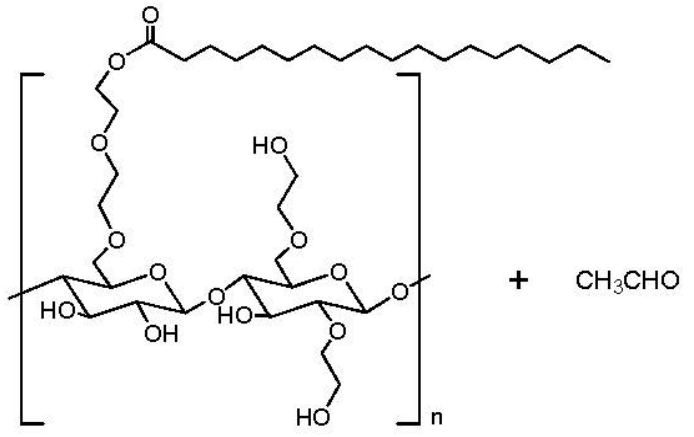

Stearoyl-HEC

Alkyl ketene dimers (AKD) are well known materials, prepared by the $2+2$ addition reaction of ketenes from long-chain fatty acids (Figure 6). They are widely used as sizing agents on paper [29,30].

Figure 6. Formation of alkyl ketene dimers.

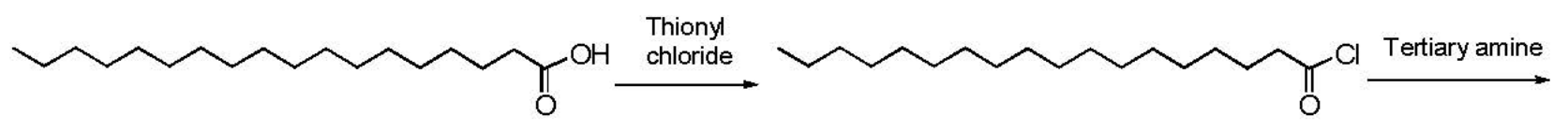

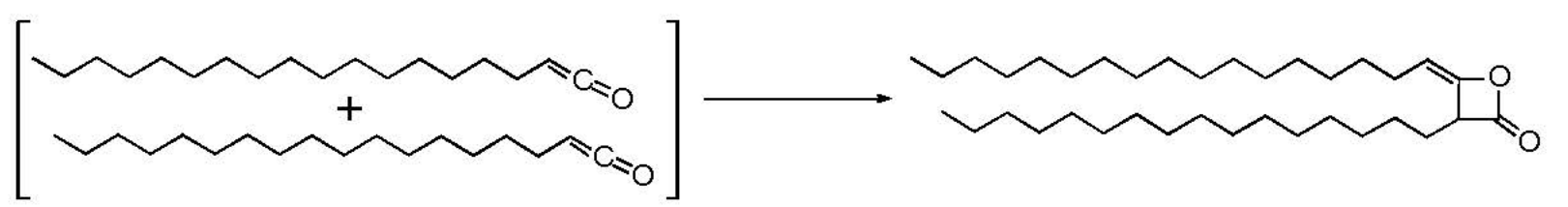

An enzymatic method was developed to graft AKD onto polysaccharides [31,32]. An example of the reaction for HEC is shown in Figure 7. The reaction can also be achieved chemically, but the enzyme approach has the advantage of mild reaction conditions and high efficiencies. The resulting product is a hydrophobically modified water-soluble polymer and has interesting surface-active and rheological properties.

Figure 7. Lipase-catalyzed reaction of alkyl ketene dimers (AKD) with HEC.

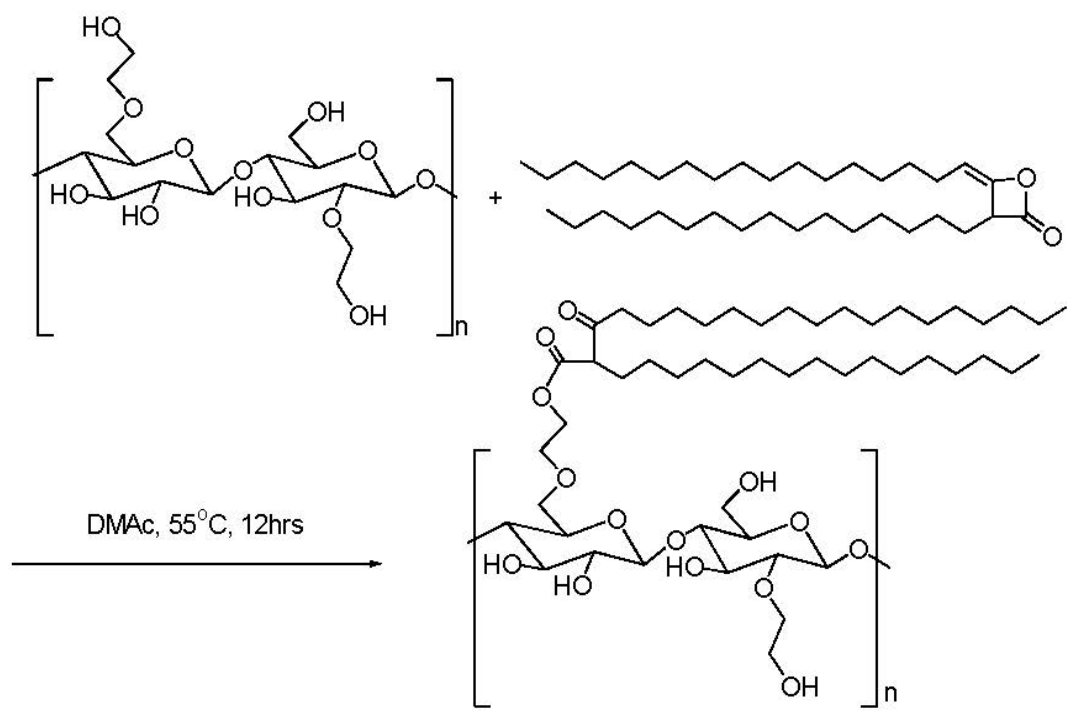


In a typical synthesis [31], HEC with degree of substitution of about 2.5 was suspended in an organic solvent. AKD and a lipase (e.g., from Pseudomonas sp. or Pseudomonas fluorescens) were added. Several AKD-modified HEC esters were reported (Table 2) at 1:100 AKD/HEC weight ratio (DS $<0.01$ ), and the viscosities of the $\mathrm{AKD} / \mathrm{HEC}$ esters were significantly improved as compared to the starting HEC. It was found that the viscosities remain unchanged after 3 days at $\mathrm{pH} 6.5$ or $\mathrm{pH} 8.5$.

Table 2. Alkyl ketene dimers (AKD)/hydroxyethylcellulose (HEC) esters and their Brookfield viscosities (BV), taken from [31].

\begin{tabular}{cccc}
\hline HEC sample & Molecular weight & HEC BV (cps, \% in water) & AKD/HEC Ester BV (cps, \% in water) \\
\hline 1 & 90,000 & $<5(2 \%)$ & $30(2 \%)$ \\
2 & 300,000 & $20(1 \%)$ & $5,600(1 \%)$ \\
3 & 720,000 & $340(1 \%)$ & $14,500(1 \%)$ \\
4 & $1,100,000$ & $1,050(1 \%)$ & $17,500(1 \%)$ \\
\hline
\end{tabular}

\subsection{Addition of a Customized Functionality}

In addition to the above reactions, sometimes it is necessary to graft a specific functionality to a polysaccharide. An example is the grafting of a vinyl group to HEC (Figure 8). Lipase from P. cepacia (Lipase PS, Amano) and Celite-immobilized bacterial alkaline protease (Alcalase, Novozymes A/S) can be used to catalyze this reaction [28,33]. The grafted HEC formed a strong crosslinked gel in DMAc at $5 \%$ upon heating to $80^{\circ} \mathrm{C}$, indicating covalent bonding of acrylate to HEC.

Figure 8. Reaction of vinyl acrylate with HEC, using protease as a catalyst.

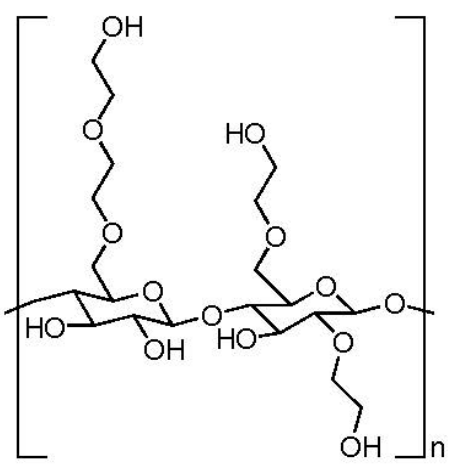

HEC

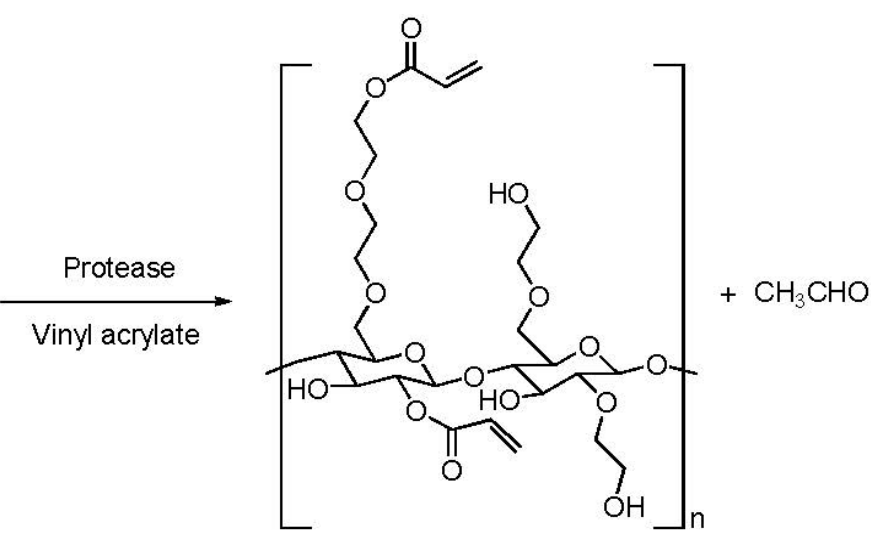

Acrylated-HEC

Another useful functionality is the acetoacetonate group, which is known to complex with metal ions. The reaction of HEC with diketene in the presence of a lipase was shown [34] to produce the requisite structure and the expected properties (Figure 9). 
Figure 9. Lipase-catalyzed reaction of diketene with HEC to form an acetoacetonate substituent.

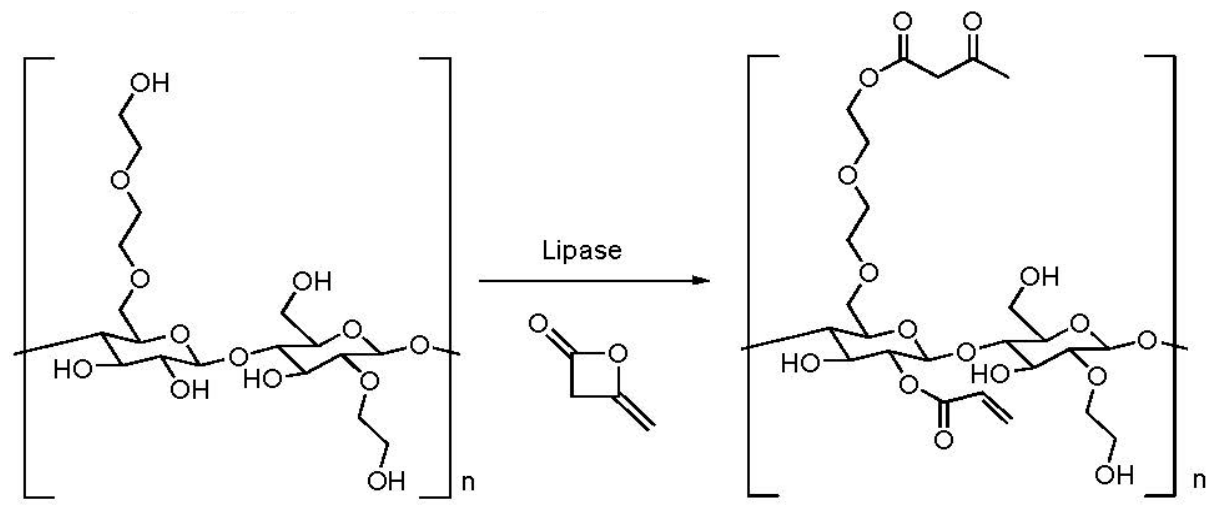

A different approach is to graft galactose onto HEC using lactose and $\beta$-galactosidase. The galactose moiety is transferred to the hydroxyl group in HEC while glucose is discarded (Figure 10). As indicated earlier, the position of the galactose additive is only shown schematically in Figure 10; in actuality galactose is substituted statistically on available $\mathrm{OH}$ units. Moreover, the C-6 hydroxy of galactose can be oxidized to an aldehyde via galactose oxidase in a subsequent reaction [35-37].

Figure 10. Glycosylation of HEC with galactose through lactose- $\beta$-galactosidase reaction.

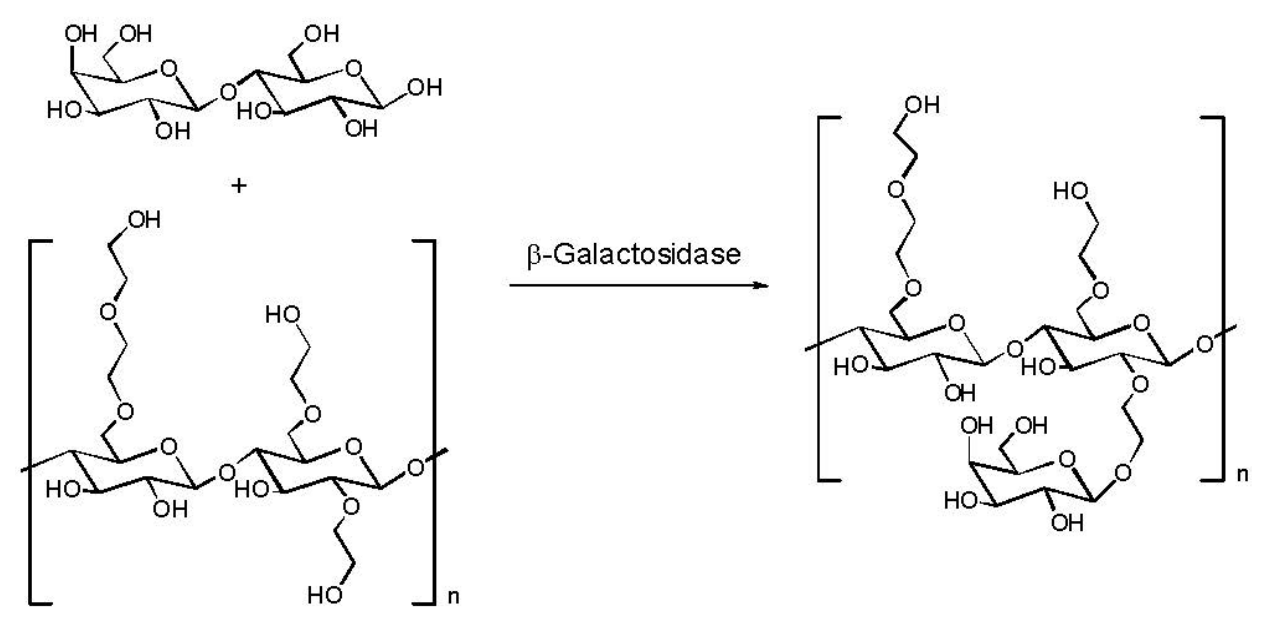

\subsection{Reduction of Molecular Weight}

In many applications, polysaccharides with lower molecular weights are useful. In commercial processes, two chemical methods are used, viz., hydrolysis with mineral acids and oxidation with hydrogen peroxide [38-40]. Enzymes pose an alternative method and have the advantage of milder reaction conditions, less colored products and reduced undesirable by-products. Most cellulosic derivatives are amenable to enzymatic hydrolysis especially when adjacent glucose residues are not substituted [41,42]. An example of CMC hydrolysis is given in Figure 11. 
Figure 11. Enzyme-catalyzed reduction of molecular weight.

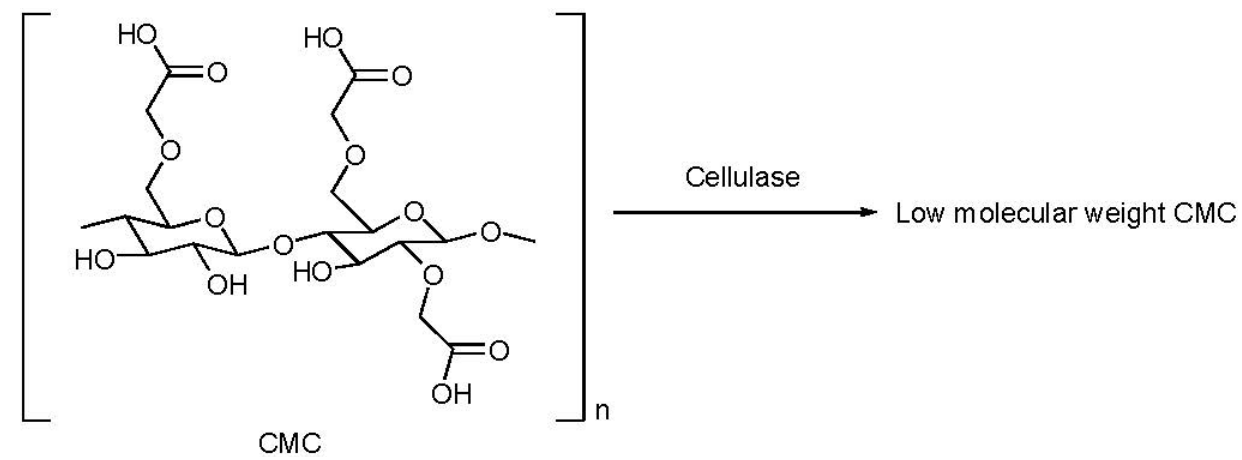

\section{Guar}

Guar gum consists mostly of a galactomannan, with a mannose: Galactose ratio of about 1.8:1.0 [1,2]. It has a high molecular weight and is used as a thickener and rheology modifier. It also finds applications in foods, in fracturing fluids in oil drilling, and as a dry strength agent in papermaking.

\subsection{Hydrolysis Reactions}

Several of the bonds in the guar structure are susceptible to enzymatic action, as shown in a simplified scheme in Figure 12.

Figure 12. Structure of guar and bonds susceptible to enzymes.

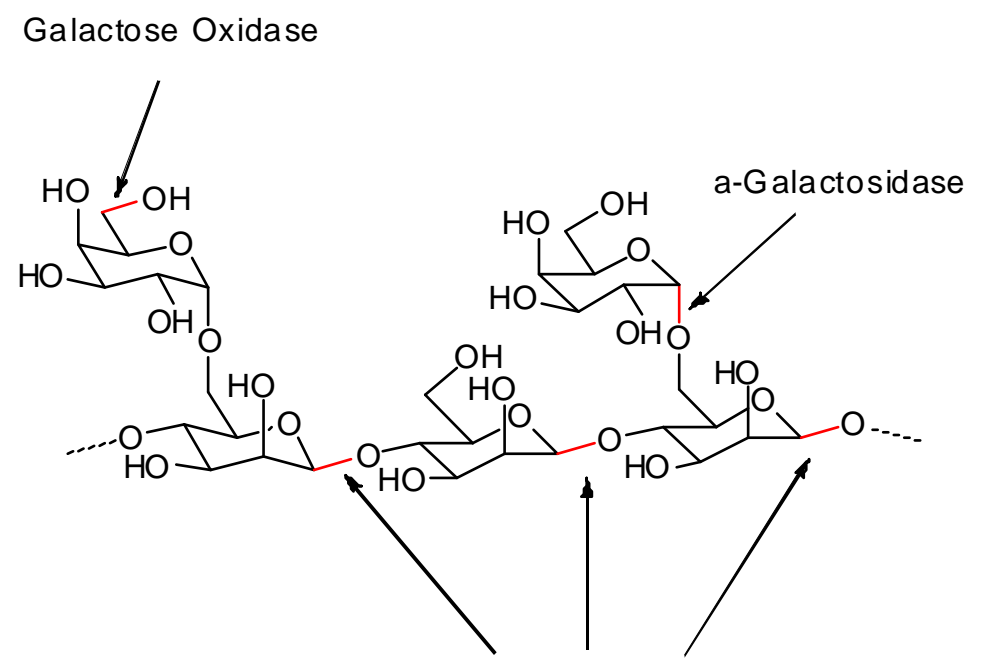

Mannanase or Hemicellulase

It is known from the literature that in the presence of mannanase, the molecular weight of guar can be reduced [43-45]. In a combinatorial experiment [46], the degradation of guar was reported in the presence of four enzymes (lipase, hemicellulase, pectinase, and protease). As expected, hemicellulase catalyzed a large decrease in molecular weight. The combination of hemicellulase and protease gave the lowest molecular weights achieved. This result is perhaps not surprising in view of the fact that guar gum contains up to $7 \%$ proteins. Thus, the protein in guar is a likely contributor to the observed molecular weight of guar. 
A good example of side-chain hydrolysis is the removal of galactose from guar using $\alpha$-galactosidase [47,48], pullulanase [49,50], and pectinase [51]. In this way, the mannose: galactose ratio can be decreased with attendant changes in its gelling tendency. A study of guar rheology in the presence of three enzymes was reported; decreased viscosity was found and a rheokinetic model was used to model the synergistic hydrolysis reactions [52]. In another study [53] guar was treated with $\alpha$-galactosidase to lower galactose content, oxidized with galactose oxidase, and epimerized using mannuronan C5-epimerases to obtain pseudo-alginates.

\subsection{Addition of Charged Functionality}

An example of the addition of an anionic group to guar is shown for the following acylation reaction (Figure 13), yielding randomly substituted products. Lipase AK (Pseudomonas sp., Amano) was found to have excellent activity for this reaction, giving maleated guar [15].

Figure 13. Synthesis of maleated guar.

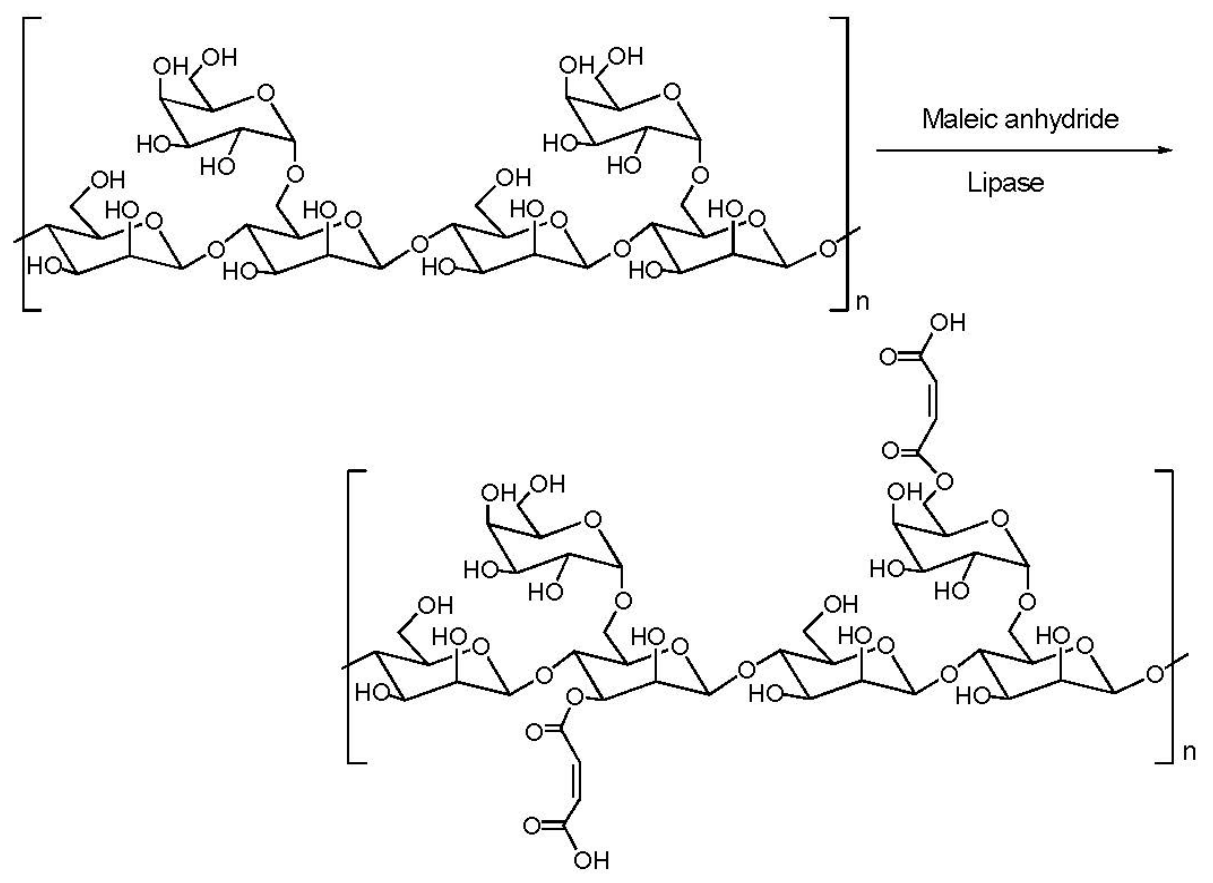

The same reaction worked equally well with succinic anhydride in the presence of a lipase to produce succinated guar [46]. Three lipases, Lipase AK, Lipase CC (from Candida cylindracea, Sigma) and Lipase OF-360 (from C. cylindracea, Meito Sangyo, Tokyo), were screened for this modification reaction. Lipase $\mathrm{AK}$ showed the highest catalytic activity for the acylation of polysaccharide, and Lipase CC the lowest activity.

\subsection{Addition of Hydrophobic Substitution}

Hydrophobic modification of cationic guar was achieved in the same way as cellulosic derivatives (Figure 14) [28]. Enzymatic reaction was found to perform very well (conversion $>90 \%$ ) when the starting material was dissolved or swollen in DMAc. However, when the same enzymatic reaction was applied to guar gum instead of its cationic guar derivative, the ester formation was very low. 
Figure 14. Hydrophobic modification of cationic guar.

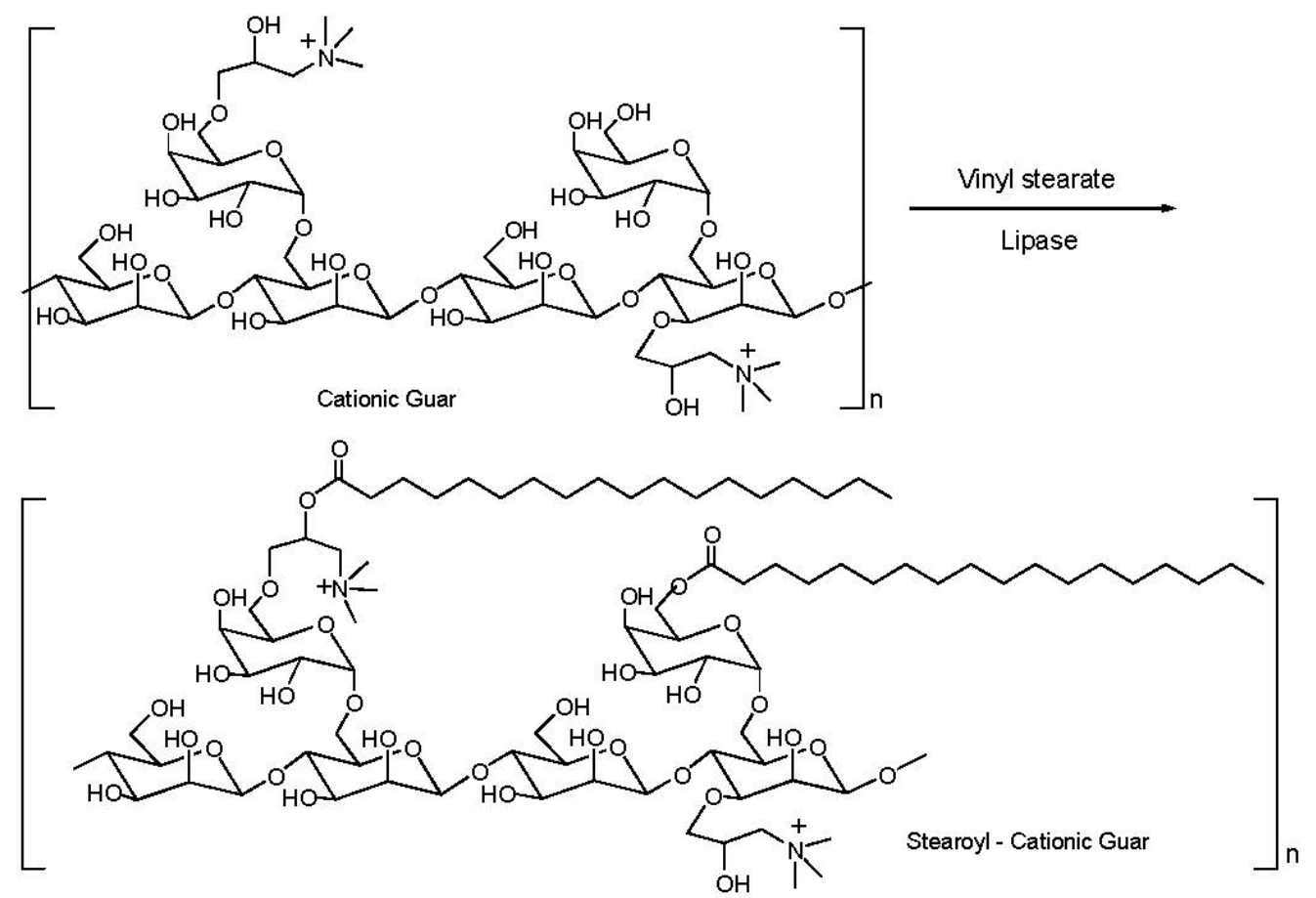

The reaction shown in Figure 14 could also proceed, albeit at lower efficiency, using palmitic acid and cationic guar in an aqueous buffer. The efficiency could be improved by adding a small amount of DMF to water [14]. In contrast, underivatized guar gave no reaction under the same reaction conditions [14]. This synthesis entailed the use of unmodified fatty acid and was carried out in water. Thus, this represented a normally unfavorable case: there was no convenient leaving group and water was present in abundance. This reaction was possible due to the interaction of the enzyme with the cationic charge on guar, which favored the ester formation even in the presence of water.

The AKD reaction (Figure 7) mentioned in the previous section was also attempted on guar [32]. Novozym $^{\circledR} 435$ lipase was found to be an appropriate enzyme with t-butyl methyl ether as reaction medium. The product was obtained at $88 \%$ efficiency. The resulting AKD/guar ester even at low DS (less than 0.01 ) showed increased viscosity in water relative to unmodified guar.

\subsection{Addition of Customized Functionality}

Guar can readily acquire, through galactose oxidase, a reactive aldehyde functionality in the C6 position [54-59]. This structure was shown to improve the dry strength of paper [56-59]. Other enzymes have also been reported to carry out this oxidation $[60,61]$.

\section{Starch}

Many enzymatic reactions have been reported for starch, and it would require a separate book or article to review all relevant starch enzymes and their reactions [62,63]. Many of these enzymes, such as amylase and pullulanase, deal with hydrolysis and debranching [64-68]. In the context of the present article, most of the enzyme-catalyzed reactions described in the previous sections also pertain to starch. For example, the AKD reaction was also demonstrated for starch (Figure 15) [69]; the lipase 
from $P$. fluorescens gave excellent results for this reaction, although porcine pancreatic lipase (PPL) and Novozym $^{\circledR} 435$ lipase also performed well. In addition to $\mathrm{AKD}$ reaction, several other enzyme-catalyzed modifications of starch have been reported recently [70-73].

Figure 15. Enzyme-Catalyzed Formation of Starch Alkyl $\beta$-Ketone Ester.
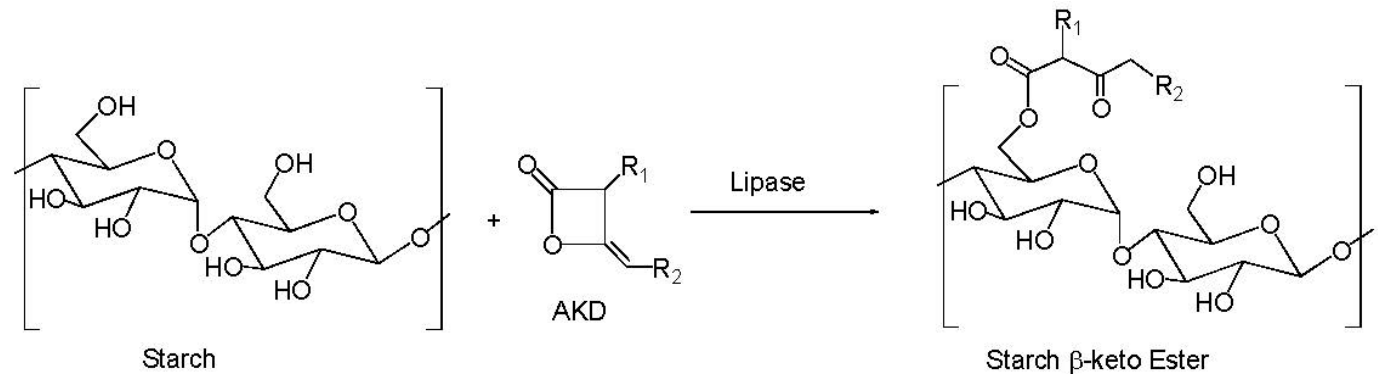

\section{Pectin}

Pectin has a complex structure that includes linear chains of $\alpha-(1-4)$-linked $D$-galacturonic acid and its ester [1,2]. Pectin properties depend partly on the amount of acid and methyl ester present. High methoxy (HM) pectin (with $>50 \%$ methyl ester) forms gels with sucrose, and low methoxy (LM) pectin (with $<50 \%$ ester) forms gels with $\mathrm{Ca}^{++}$ions. Pectins are susceptible to enzymatic actions [74,75]. For example, alkaline pectinases (which comprise polygalacturonases, pectin lyases, pectate lyases, and pectin esterases) have found many industrial applications, such as bioscouring of cotton, oil extraction, treatment of industrial wastewater, and papermaking [76-78]. The reactions of many specific pectic enzymes have been well studied, e.g., pectin methylesterase [79-82], polygalacturonase [83,84], and pectin lyase $[85,86]$. Studies with proteases have shown the importance of proteinaceous moiety in emulsifying properties of pectin $[87,88]$. Laccase and peroxidase have been used to crosslink ferulic acid in sugarbeet pectin $[89,90]$.

An interesting reaction was reported that catalyzed the grafting of glycerol to pectin under mild conditions through enzymatic esterification (Figure 16) [20]. A large number of lipases and esterases have been screened. By the use of porcine pancreatic lipase (PPL) or lipase OF-360, a glycerol-pectin adduct was produced, in which the $\mathrm{C}_{1}$ of the glycerol formed a monoester with the HM pectin. No glycerol diester (i.e., crosslinked structure) was found. The reaction was highly specific, similar to the enzymatic synthesis of the amine-containing CMC-amide as mentioned in Section 2.

Figure 16. Lipase-catalyzed addition of glycerol to pectin.

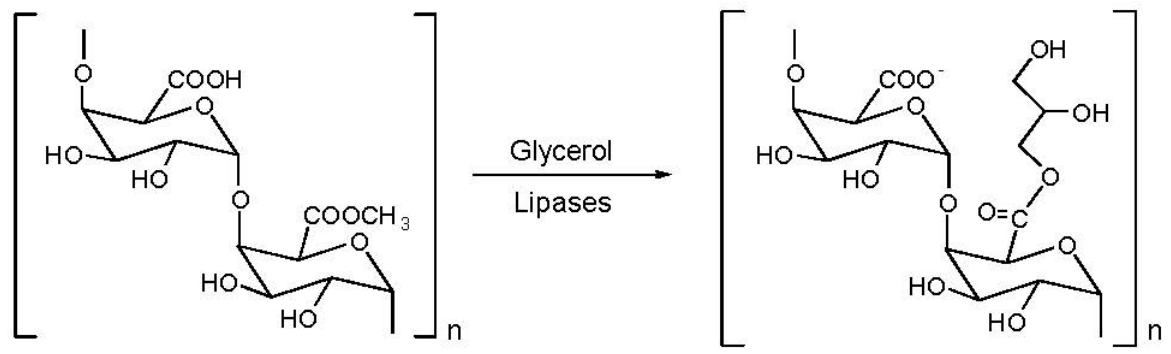


Another useful reaction was found with commercial papaya latex papain (a non-specific protease). When papain was added to HM pectin and an amino acid in water, the amino acid could be grafted onto the pectin through aminolysis of the pectin methyl ester (Figure 17) [91,92]. Pectin is usually not a substrate of papain, and this reaction was unexpected. Subsequent work indicated that a minor protein component of commercial papain actually catalyzed this reaction.

Figure 17. Papain-catalyzed grafting of amino acid onto high methoxy (HM) pectin.
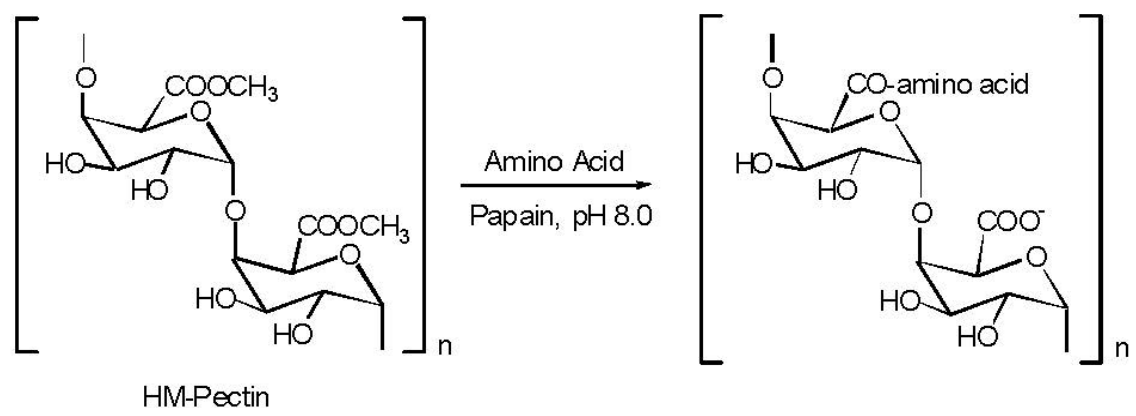

This reaction was generally valid for all amino acids and some amines. However the gelling tendency of the reaction product varied with the amino acid used. It was noticed that HM pectin modified with the basic amino acids, e.g., lysine and arginine, produced the best gels [92]. Some typical results are shown in Table 3. The additive: Pectin weight ratio is 20:100, with DS 0.2 or less.

Table 3. Reaction of selected amino acids and amines with HM pectin and papain, taken from [92].

\begin{tabular}{ll}
\hline Additive & Observation \\
\hline Arginine & strong gel \\
Lysine & soft gel \\
Phenylalanine & cloudy liquid \\
Tyrosine & cloudy liquid \\
Tryptophan & cloudy liquid \\
Threonine & cloudy liquid \\
Serine & Liquid \\
Cysteine & Liquid \\
Alanine & Very soft gel after $3 \mathrm{~h}$ at rt. \\
1-(3-Aminopropyl)imidazole & soft gel \\
Diethylene triamine & soft gel \\
\hline
\end{tabular}

\section{Poly(ethylene glycol)}

Although not a polysaccharide, poly(ethylene glycol) (PEG) is a water-soluble polymer that is used in some of the same applications as polysaccharides. Many enzyme-catalyzed reactions can be performed on PEG in a similar fashion as polysaccharides. For example, through the use of lactose and $\beta$-galactosidase, galactose was grafted onto the chain end of PEG (Figure 18) [20]. The reaction was relatively facile and entailed mixing poly(ethylene glycol), $\beta$-galactosidase, and lactose in water and stirring for a period of time at room temperature. Interestingly, the galactosidase from Escherichia coli did not produce the desired glycosylation, whereas the galactosidase from Aspergillus oryzae worked. 
Figure 18. Formation of galactosylated poly(ethylene glycol) (PEG) through lactose- $\beta$-galactosidase reaction.
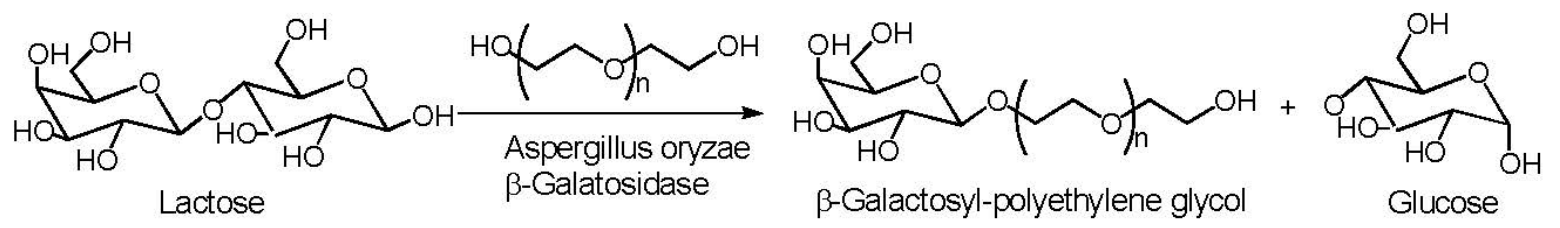

Another example is the addition of fatty acid to the PEG chain end [20]. Thus, an amine-terminated PEG (MW 500-2,000) was reacted with methyl palmitate under mild conditions $\left(<45^{\circ} \mathrm{C}, 3-5 \mathrm{~h}\right)$ without a solvent in the presence of Novozym ${ }^{\circledR} 435$ to form a surfactant (Figure 19). The amount of the disubstituted adduct could be adjusted by using more methyl palmitate in the starting reaction mixture. Simply heating the amine-terminated PEG with methyl palmitate up to $100{ }^{\circ} \mathrm{C}$ in the absence of the enzyme did not form the desired products.

Figure 19. Lipase-catalyzed amidation of PEG.<smiles>[R]C(=O)NC(C)(C)CCOC(C)(C)CN</smiles>

The fatty diester of PEG is known to be a good surfactant; commercial products employ chemical methods to achieve the required synthesis. Enzymatic methods can also be used; however, the reaction needs to be optimized [14]. An example is the lipase-catalyzed synthesis of fatty acid diester of poly(ethylene glycol) (PEG) (Figure 20).

Figure 20. Lipase-catalyzed synthesis of PEG diester.<smiles>[R]C(=O)OCC(C)(C)OCCC(C)(C)OC([R])OC(C)(C)COC(C)(C)COCC(C)(C)O</smiles>

A number of commercial lipases was screened for substrate selectivity towards the esterification of the fatty acid and PEG. Lipases from Candida antarctica and Mucor miehei were found to have a strong preference for the fatty acid. The C. antarctica lipase was chosen because it gave faster rates. The reaction was initiated by adding the enzyme to bulk PEG and fatty acid (at a 1.0:1.9 mole ratio). The conversion was low even at different temperatures, and a mixture of monoesters and diesters was obtained. However, by pulling a vacuum, high conversions could be achieved at $50-60{ }^{\circ} \mathrm{C}$ in $8-48 \mathrm{~h}$. The final product was isolated by filtration, which also recovered the enzyme for reuse [14].

The AKD reaction (Figure 7) has been extended to PEG [32]. An appropriate reaction medium was found to be DMF. In this case, PEG, AKD, and Lipase AK were added together and stirred at $50{ }^{\circ} \mathrm{C}$ for $72 \mathrm{~h}$. The desired product was obtained at $90 \%$ conversion. 


\section{Conclusions}

In this review it has been shown that enzymatic reactions are useful methods for polysaccharide modifications. These modification reactions include ester formation, transesterification, amidation, oxidation, glycosylation, and polymer molecular weight reduction. A summary of major concepts and useful practical information is provided below.

(a) Most of the polysaccharide modifications need not be carried out to very high DS to give the desired end-use properties; thus, enzymatic reactions do not necessarily have to entail high conversion yields to be useful. For example, hydrophobic modification of HEC and guar only needs to be carried out to DS of 0.1 (or less) to produce a significant effect on physical properties, such as high viscosity and shear thinning behavior. Similarly, the DS for the amino acid or diamine substitution can be 0.2 (or less) to induce the formation of pectin gels.

(b) If a desired polysaccharide modification is needed, a scouting study is usually first carried out to check for the feasibility with specific substrates and enzymes. In order to achieve best results, the modification reaction needs to be optimized with particular care paid to the choice of the enzyme and the solvent medium.

(c) Most solvent media used are polar aprotic solvents, water, or mixed solvents. Preferably both the starting material and the final product are either soluble or swellable in the solvent media. Examples of often used solvents are DMF, DMAc, $N$-methyl pyrrolidone, butyl methyl ether, or aqueous buffer. If an aqueous buffer is used, the $\mathrm{pH}$ needs to be optimized for the reaction. (Note that each enzyme usually has its own optimal operating $\mathrm{pH}$ range.) Sometimes it is possible to carry out the enzymatic reaction without a solvent (e.g., HEC-caprolactone and pectin-glycerol); in such cases, the enzymes used for the reaction should be mostly dry but contain a trace amount of water for optimal results. A good way is to use a freeze dried enzyme for the modification reaction.

(d) If a new enzymatic reaction is being attempted, it would be useful initially to use an artificially high level of an enzyme (as much as $10 \%-20 \%$ of the weight of the polysaccharide) together with different stoichiometries of the reactants. If the reaction is shown to work, then the enzyme level can be scaled back later in an optimization process. The stoichiometry of the reactants can also be optimized.

(e) The reaction temperature can be varied in the optimization process. Note that most enzymes undergo increasing degrees of denaturation at higher temperatures (approximately $70{ }^{\circ} \mathrm{C}$ or higher). This upper temperature limit can be raised for special enzymes from extremophiles or from directed evolution, up to $90{ }^{\circ} \mathrm{C}$ in some cases.

(f) Some enzymatic reactions involve the co-generation of a small molecule as a byproduct (e.g., acetaldehyde, methanol, and water). For these reactions, often it is possible to increase the reaction rate or yield by pulling a vacuum or decreasing the pressure in the reaction vessel in order to remove the small molecule. In the case of water, an alternative is to use a dehydrating agent (e.g., molecular sieves) in the reaction mixture.

(g) Some enzymes can be expensive. In order to decrease the cost, the enzyme can be immobilized on a solid support and reused. Some commercial enzymes are already available on a solid support (e.g., Novozym ${ }^{\circledR} 435$ lipase). 
(h) Enzyme screening is a major part of the scouting study and sometimes surprises are encountered [33]. In view of the many different approaches currently used to produce new or improved enzymes [93-98], more enzyme-mediated reactions on polysaccharides can be expected in the future.

\section{Acknowledgments}

Thanks are due to Suhad Wojkowski for literature search and K. Thomas Klasson for encouragement. Mention of trade names or commercial products in this publication is solely for the purpose of providing specific information and does not imply recommendation or endorsement by the U.S. Department of Agriculture; USDA is an equal opportunity provider and employer.

\section{References}

1. Whistler, R.L.; BeMiller, J.N. Industrial Gums, 3rd ed.; Academic Press: San Diego, CA, USA, 1993.

2. Stephen, A.M.; Phillips, G.O.; Williams, P.A. Food Polysaccharides and Their Applications, 2nd ed.; CRC Press: Boca Raton, FL, USA, 2006.

3. Cheng, H.N.; Cote, G.L.; Baianu, I.C. Application of Polymers in Foods (Macromolecular Symposia 140); Wiley-VCH: Weinheim, Germany, 1999.

4. Heinze, T.J.; Glasser, W.G. Cellulose Derivatives. Modification, Characterization, and Nanostructures (ACS Symp. Ser. 688); American Chemical Society: Washington, DC, USA, 1998.

5. Heinze, T.; Libert, T.; Koschella, A. Esterification of Polysaccharides; Springer-Verlag: Berlin, Germany, 2006.

6. Ashland. Available online: http://www.ashland.com (accessed on 9 March 2012).

7. Dow Wolff Cellulosics. Available online: http://www.dow.com/dowwolff/en/ (accessed on 9 March 2012).

8. Loos, K. Biocatalysis in Polymer Chemistry; Wiley-VCH: Weinheim, Germany, 2011.

9. Cheng, H.N.; Gross, R.A. Green Polymer Chemistry: Biocatalysis and Biomaterials (ACS Symp. Ser. 1043); American Chemical Society: Washington, DC, USA, 2010.

10. Cheng, H.N.; Gross, R.A. Polymer Biocatalysis and Biomaterials II (ACS Symp. Ser. 999); American Chemical Society: Washington, DC, USA, 2008.

11. Roberts, S.M. Biocatalysis for Fine Chemicals Synthesis; Wiley: Chichester, UK, 1999.

12. Faber, K. Biotransformations in Organic Chemistry, 3rd ed.; Springer: Berlin, Germany, 1997.

13. Drauz, K.; Waldemann, H. Enzyme Catalysis in Organic Synthesis; VCH: Weinheim, Germany, 1995.

14. Gu, Q.-M.; Cheng, H.N. Enzyme-catalyzed condensation reactions for polymer modification. ACS Symp. Ser. 2005, 900, 427-436.

15. Gu, Q.-M.; Cheng, H.N. Enzyme-Catalyzed reactions of polysaccharides. ACS Symp. Ser. 2003, 840, 203-216.

16. Gubitz, G.M.; Paulo, A.C. New substrates for reliable enzymes: Enzymatic modification of polymers. Curr. Opin. Biotechnol. 2003, 14, 577-582.

17. McCleary, B.V. Enzymatic modification of plant polysaccharides. Int. J. Biol. Macromol. 1986, 8, 349-354. 
18. Li, J.; Xie, W.; Cheng, H.N.; Nickol, R.G.; Wang, P.G. Polycaprolactone-modified hydroxyethylcellulose films prepared by lipase-catalyzed ring-opening polymerization. Macromolecules 1999, 32, 2789-2792.

19. Hu, S.; Gao, W.; Kumar, R.; Gross, R.A.; Gu, Q.-M.; Cheng, H.N. Lipase-mediated selective TEMPO oxidation of hydroxyethylcellulose. ACS Symp. Ser. 2003, 840, 253-264.

20. Cheng, H.N.; Gu, Q.-M. Enzymatic modifications of water-soluble polymers. ACS Polym. Prepr. 2000, 41, 1873-1874.

21. Glass, J.E. Associative Polymers in Aqueous Media (ACS Symp. Ser. 765); American Chemical Society: Washington, DC, USA, 2000.

22. Landoll, L.M. Nonionic polymer surfactants. J. Polym. Sci. Polym. Chem. Ed. 1982, 20, 443-455.

23. Emmons, W.D.; Stevens, T.E. Polyurethane thickeners in latex compositions. U.S. Patent 4,079,028, 14 March 1978.

24. Lundberg, D.J.; Brown, R.G.; Glass, J.E.; Eley, R.R. Synthesis, characterization, and solution rheology of model hydrophobically-modified, water-soluble ethoxylated urethanes. Langmuir 1994, 10, 3027-3034.

25. Shay, G.D.; Eldridge, E.; Kail, E. Alkali soluble latex thickeners. U.S. Patent 4,514,552, 30 April 1985.

26. Shay, G.D.; Kravitz, F.K.; Brizgys, P.V.; Kersten, M.A. Production of alkali-soluble, carboxyl-functional aqueous emulsion thickeners. U.S. Patent 4,801,671, 31 January 1989.

27. Shay, G.D.; Kravitz, F.K.; Brizgys, P.V. Effects of process variables on the emulsion and solution properties of hydrophobically modified alkali-swellable emulsion thickeners. ACS Symp. Ser. 1991, 462, 121-141.

28. Gu, Q.-M. Lipase-catalyzed grafting reactions on polysaccharides. ACS Symp. Ser. 2003, 840, 243-247.

29. Reynolds, W.F. The Sizing of Paper, 2nd ed.; TAPPI: Atlanta, GA, USA, 1989.

30. Lindstrom, T.; Larsson, P.T. Alkyl ketene dimer (AKD) sizing-a review. Nordic Pulp Paper Res. J. 2008, 23, 202-209.

31. Cheng, H.N.; Gu, Q.-M. Esterified polysaccharide products with ketene dimer by beta-lactone ring opening. U.S. Patent 6,528,643, 4 March 2003.

32. Gu, Q.-M.; Cheng, H.N. Enzyme-catalyzed esterification of cellulosics, guar, and polyethers. ACS Polym. Prepr. 2005, 46, 30-31.

33. Cheng, H.N.; Gu, Q.-M.; Qiao, L. Reactions of enzymes with non-substrate polymers. ACS Symp. Ser. 2005, 900, 267-278.

34. Wang, P.G.; Xie, W.; Qiao, L.; Nickol, R.G.; Cheng, H.N. Actoacetylated saccharides and process of making the same. U.S. Patent 6,528,644, 4 March 2003.

35. Gu, Q.-M. Enzyme-mediated reactions of oligosaccharides and polysaccharides. ACS Symp. Ser. 2001, 786, 184-194.

36. Li, J.; Cheng, H.N.; Nickol, R.G.; Wang, P.G. Enzymatic modification of hydroxyethylcellulose by transgalactosylation with beta-galactosidase. Carbohydr. Res. 1999, 316, 133-137.

37. Cheng, H.N.; Li, J.; Nickol, R.G.; Wang, P.G. Galactosylated hydroxyalkyl polysaccharides and their derivatives and enzymatic process for manufacture. U.S. Patent 6,433,161, 13 August 2002.

38. Vink, H. Degradation of some polymers in aqueous solutions. Makromol. Chem. 1963, 67, 105-123. 
39. Klemm, D.; Philipp, B.; Heinze, T.; Heinze, U.; Wagenknecht, W. Comprehensive Cellulose Chemistry; Wiley-VCH: Weinheim, Germany, 1998.

40. Ott, E.; Spurlin, H.M.; Grafflin, M.W. Cellulose and Cellulose Derivatives; Interscience: New York, NY, USA, 1954.

41. Saake, B.; Horner, S.; Puls, J. Progress in the enzymatic hydrolysis of cellulose derivatives. ACS Symp. Ser. 1998, 688, 201-216.

42. Sau, A.C. Biostable water-borne paints and processes for their preparation. U.S. Patent 5,879,440, 8 March 1999.

43. Tayal, A.; Kelly, R.M.; Khan, S.A. Rheology and molecular weight changes during enzymatic degradation of a water-soluble polymer. Macromolecules 1999, 32, 294-300.

44. Cheng, Y.; Prud'homme, R.K. Reaction-diffusion of enzyme molecules in biopolymer matrices. ACS Symp. Ser. 2003, 840, 265-284.

45. Mahammad, S.; Prudhomme, R.K.; Roberts, G.W.; Khan, S.A. Kinetics of enzymatic depolymerizaton of guar galactomannan. Biomacromolecules 2006, 7, 2583-2590.

46. Cheng, H.N.; Gu, Q.-M. Biotransformation of Polysaccharides. In Glycochemistry: Principles, Synthesis, and Applications; Wang, P.G., Bertozzi, C.R., Eds.; Marcel Dekker: New York, NY, USA, 2001; pp. 567-579.

47. MacCleary, B.V.; Critchley, P.; Bulpin, P.V. Process of polysaccharides. U.S. Patent 5,234,825, 10 August 1993.

48. Bulpin, P.V.; Gidley, M.J.; Jeffcoat, R.; Underwood, D.R. Development of a biotechnological process for the modification of galactomannan polymers with plant $\alpha$-galactosidase. Carbohydr. Polym. 1990, 12, 155-168.

49. Shobha, M.S.; Tharanathan, R.N. Rheological behavior of pullulanase-treated guar galactomannan on co-gelation with xanthan. Food Hydr. 2009, 23, 749-754.

50. Shobha, M.S.; Tharanathan, R.N. Nonspecific activity of Bacillus acidopullulyticus pullulanase on debranching of guar galactomannan. J. Agric. Food. Chem. 2008, 56, 10858-10864.

51. Shobha, M.S.; Kumar, A.B.V.; Tharanathan, R.N.; Koka, R.; Gaonkar, A.K. Modification of guar galactomannan with the aid of Aspergillus niger pectinase. Carbohydr. Polym. 2005, 62, 267-273.

52. Mahammad, S.; Comfort, D.A.; Kelly, R.M.; Khan, S.A. Rheological properties of guar galactomannan solutions during hydrolysis with galactomannanase and alpha-galactosidase enzyme mixtures. Biomacromolecules 2007, 8, 949-956.

53. Crescenzi, V.; Dentini, M.; Risica, D.; Spadoni, S.; Skjak-Braek, G.; Capitani, D.; Mannina, L., Viel, S. C(6)-oxidation followed by C(5)-epimerization of guar gum studied by high field NMR. Biomacromolecules 2005, 5, 537-546.

54. Yalpani, M.; Hall, L.D. Some chemical and analytical aspects of polysaccharide modifications. II. A high-yielding, specific method for the chemical derivatization of galactose-containing polysaccharides: Oxidation with galactose oxidase followed by reductive amination. J. Polym. Sci. Polym. Chem. Ed. 1982, 20, 3399-3420.

55. Frollini, E.; Reed, W.F.; Milas, M.; Rinaudo, M. Polyelectrolytes from polysaccharides: Selective oxidation of guar gum - a revisited reaction. Carbohydr. Polym. 1995, 27, 129-135.

56. Chiu, C.-W.; Jeffcoat, R.; Henley, M.; Peek, L. Aldehyde cationic derivatives of galactose containing polysaccharides used as paper strength additives. U.S. Patent 5,554,745, 10 September 1996. 
57. Brady, R.L.; Leibfried, R.L. Use of oxidation promoting chemicals in the oxidation oxidizable galactose type of alcohol configuration containing polymer. U.S. Patent 6,022,717, 8 February 2000.

58. Brady, R.L.; Leibfried, R.L.; Nguyen, T.T. Oxidation in solid state of oxidizable galactose type of alcohol configuration containing polymer. U.S. Patent 6,124,124, 26 September 2000.

59. Brady, R.L.; Leibfried, R.L.; Nguyen, T.T. Paper having improved strength characteristics and process for making same. U.S. Patent 6,179,962, 30 January 2001.

60. Lavazza, M.; Formantici, C.; Langella, V.; Monti, D.; Pfeiffer, U.; Galante, Y.M. Oxidation of galactomannan by laccase plus TEMPO yields an elastic gel. J. Biotechnol. 2011, 156, 108-116.

61. Parikka, K.; Lappanen, A.S.; Pitkanen, L.; Ruenanen, M.; Willfor, S.; Tenkanen, M. Oxidation of polysaccharides by galactose oxidase. J. Agric. Food Chem. 2010, 58, 262-271.

62. Godfrey, T.; West, S. Industrial Enzymology, 2nd ed.; Stockton Press: New York, NY, USA, 1996; pp. 227-264.

63. White, J.S.; White, D.C. Source Book of Enzymes; CRC Press: New York, NY, USA, 1997.

64. Abbas, K.A.; Kalil, S.K.; Hussin, A.S.M. Modified starches and their usages in selected food products: A review study. J. Agric. Sci. 2010, 2, 90-100.

65. Zhang, H.X.; Jin, Z.Y. Preparation of products rich in resistant starch from maize starch by an enzymatic method. Carbohydr. Polym. 2011, 86, 1610-1614.

66. Lee, K.Y.; Lee, S.; Lee, H.G. Effect of the degree of enzymatic hydrolysis on the physicochemical properties and in vitro digestibility of rice starch. Food Sci. Biotechnol. 2010, 19, 1333-1340.

67. Khatoon, S.; Sreerama, Y.N.; Raghavendra, D.; Hhattacharya, S.; Bhat, K.K. Properties of enzyme modified corn, rice and tapioca starches. Food Res. Int. 2009, 42, 1426-1433.

68. Karim, A.A.; Sufha, E.H.; Zaidul, I.S.M. Dual modification of starch via partial enzymatic hydrolysis in the granular state and subsequent hydroxypropylation. J. Agric. Food Chem. 2008, 56, 10901-10907.

69. Qiao, L.; Gu, Q.-M.; Cheng, H.N. Enzyme-catalyzed synthesis of hydrophobically modified starch. Carbohydr. Polym. 2006, 66, 135-140.

70. Alissandratos, A.; Baudendistel, N.; Flitsch, S.L.; Hauer, B.; Halling, P.J. Lipase-catalysed acylation of starch and determination of the degree of substitution by methanolysis and GC. BMC Biotechnol. 2010, 10, 82-89.

71. Rajan, A.; Sudha, J.D.; Abraham, T.E. Enzymatic modification of cassava starch by fungal lipase. Ind. Crops Prod. 2008, 27, 50-59.

72. Rajan, A.; Prasad, V.S.; Abraham, T.E. Enzymatic esterification of starch using recovered coconut oil. Int. J. Biol. Macromol. 2006, 39, 265-272.

73. Chakraborty, S.; Sahoo, B.; Teraoka, I.; Miller, L.M.; Gross, R.A. Enzyme-catalyzed regioselective modification of starch nanoparticles. Macromolecules 2005, 38, 61-68.

74. Alkorta, I.; Garbisu, C.; Llama, M.J.; Serra, J.L. Industrial applications of pectic enzymes: A review. Process Biochem. 1998, 33, 21-28.

75. Kashyap, D.R.; Vohra, P.K.; Chopra, S.; Tewari, R. Applications of pectinases in the commercial sector: A review. Bioresour. Technol. 2001, 77, 215-227.

76. For example, Pedrolli, D.B.; Monteiro, A.C.; Gomes, E.; Carmona, E.C. Pectin and pectinases: Production, characterization and industrial application of microbial pectinolytic enzymes. Open Biotechnol. J. 2009, 3, 9-18. 
77. Wang, Q.; Fan, X.R.; Hua, Z.Z.; Gao, W.D.; Chen, J. Degradation kinetics of pectins by an alkaline pectinase in bioscouring of cotton fabrics. Carbohydr. Polym. 2007, 67, 572-575.

78. Hoondal, G.; Tiwari, R.; Tewari, R.; Dahiya, N.; Beg, Q. Microbial alkaline pectinases and their industrial applications: A review. Appl. Microbiol. Biotechnol. 2002, 59, 409-418.

79. Videcoq, P.; Garnier, C.; Robert, P.; Bonnin, E. Influence of calcium on pectin methylesterase behavior in the presence of medium methylated pectins. Carbohydr. Polym. 2011, 86, 1657-1664.

80. Cameron, R.G.; Luzio, G.A.; Vasu, P.; Savary, B.J.; Williams, M.A.K. Enzymatic modification of a model homogalacturonan with the thermally tolerant pectin methylesterase from citrus: 1. Nanostructural characterization, enzyme mode of action, and effect of pH. J. Agric. Food. Chem. 2011, 59, 2717-2724.

81. Jolie, R.P.; Duveter, T.; van Loey, A.M.; Hendrickx, M.E. Pectin methyesterase and its proteinaceous inhibitor: A review. Carbohydr. Res. 2010, 34, 2583-2595.

82. Pelloux, J.; Rustérucci, C.; Mellerowicz, E.J. New insights into pectin methylesterase structure and function. Trends Plant Sci. 2007, 12, 267-277.

83. Andrade, M.V.V.; Delatorre, A.B.; Silvania Alves Ladeira, S.A.; Martins, M.L.L. Production and partial characterization of alkaline polygalacturonase secreted by thermophilic Bacillus sp. SMIA-2 under submerged culture using pectin and corn steep liquor. Ciênc. Tecnol. Aliment. Camp. 2011, 31, 204-208.

84. Kiss, K.; Nemesthothy, N.; Gubicza, L.; Belafi-Bako, K. Vacuum assisted membrane bioreactor for enzymatic hydrolysis of pectin from various agro-wastes. Desalination 2009, 241, 29-33.

85. van Alebeek, G.; Christensen, T.; Schols, H.A.; Mikkelsen, J.D.; Voragen, A.G.J. Mode of action of pectin lyase A of Aspergillus niger on differently C(6)-substituted oligogalacturonides. J. Biol. Chem. 2002, 277, 25929-25936.

86. Yadav, S.; Yadav, P.K.; Yadav, D.; Yadav, K.D.S. Pectin lyase: A review. Proc. Biochem. 2009, 44, 1-10.

87. Funami, T.; Nakauma, M.; Ishihara, S.; Tanaka, R.; Inoue, T.; Phillips, G.O. Structural modifications of sugar beet pectin and the relationship of structure to functionality. Food Hydr. 2011, 25, 221-229.

88. Nuñez, A.; Fishman, M.L.; Fortis, L.L.; Cooke, P.H.; Hotchkiss, A.T. Identification of extensin protein associated with sugar beet pectin. J. Agric. Food Chem. 2009, 57, 10951-10958.

89. Zeeb, B.; Fischer, L.; Weiss, J. Crosslinking of interfacial layers affects the salt and temperature stability of multilayered emulsions consisting of fish gelatin and sugar beet pectin. J. Agric. Food. Chem. 2011, 59, 10546-10555.

90. Norsker, M.; Jensen, M.; Adler-Nissen, J. Enzymatic gelation of sugar beet pectin in food products. Food Hydr. 2000, 14, 237-243.

91. Cheng, H.N.; Gu, Q.-M.; Nickol, R.G. Amine-modified polymers, especially polysaccharides and pectins, and preparation thereof for improved gelation. U.S. Patent 6,159,721, 12 December 2000.

92. Gu, Q.-M.; Nickol, R.G.; Cheng, H.N. Enzyme-catalyzed modification of pectin. ACS Polym. Prepr. 2003, 44, 608-609.

93. Kuznetsova, E.; Proudfoot, M.; Sanders, S.A.; Reinking, J.; Savchenko, A.; Arrowsmith, C.H.; Edwards, A.M.; Yakunin, A.F. Enzyme genomics: Application of general enzymatic screens to discover new enzymes. FEMS Microbiol. Rev. 2005, 29, 263-279. 
94. Faber, K.; Kroutil, W. New enzymes for biotransformations. Curr. Opin. Chem. Biol. 2005, 9, $181-187$.

95. Haki, G.D.; Rakshit, S.K. Developments in industrially important thermostable enzymes: A review. Bioresour. Technol. 2003, 89, 17-34.

96. Cherry, J.R.; Fidantsef, A.L. Directed evolution of industrial enzymes: An update. Curr. Opin. Biotechnol. 2003, 14, 438-443.

97. Bornscheuer, U.T.; Pohl, M. Improved biocatalysts by directed evolution and rational protein design. Curr. Opin. Chem. Biol. 2001, 5, 137-143.

98. Qi, D.; Tann, C.-M.; Haring, D.; Distefano, M.D. Generation of new enzymes via covalent modification of existing proteins. Chem. Rev. 2001, 101, 3081-3112.

(C) 2012 by the authors; licensee MDPI, Basel, Switzerland. This article is an open access article distributed under the terms and conditions of the Creative Commons Attribution license (http://creativecommons.org/licenses/by/3.0/). 